\title{
LXII. First sketch of some of the principal results of a second geological survey of Russia
}

\section{Roderick Impey Murchison Esq. F.R.S.}

To cite this article: Roderick Impey Murchison Esq. F.R.S. (1841) LXII. First sketch of some of the principal results of a second geological survey of Russia, Philosophical Magazine Series 3, 19:126, 417-422, DOI: $10.1080 / 14786444108650460$

To link to this article: http://dx.doi.org/10.1080/14786444108650460

册 Published online: 01 Jun 2009.

Submit your article to this journal

Џll Article views: 8

Q View related articles $\square$ 
TH E

LONDON, EDINBURGH AND DUBLIN

PHILOSOPHICAL MAGAZINE

A N $\mathbf{~}$

JOURNAL OF SCIENCE.

[THIRD SERIES.]

$D E C E M B E R \quad$ 184.1.

LXII. First Sketch of some of the principal Results of a Second Geological Survey of Russia. Communicated by RODERICK Impey Murchison, Esq., F.R.S., President of the Geological Society.

To the Editor of the Philosophical Magazine. Dear Sir,

I $T$ was my earnest wish to have complied earlier with your 1 request when $I$ left this country, to send you from the spot some account of my distant wanderings; but the desire to avoid communicating early conceptions which might be modified by subsequent observation, induced me to stay $\mathrm{my}$ pen until I could offer something worthy of a place in the Philosophical Magazine. 'The short sketch which follows was written at Moscow near the close of the journey, and is, with some very slight alterations, the translation of a letter addressed to M. Fischer de Waldheim, the venerable and respected President of the Society of Naturalists of that metropolis. Since then, besides the official report to the Minister of Finance, the Count de Cancrine, I have submitted to His Imperial Majesty, a tabular view of all the formations in Russia, accompanied by a general map and a section from the Sea of Azof to St. Petersburgh. These documents, which will be engraved in the course of the winter, are to be considered only as the prelude to a long memoir with full illustrations of the organic remains, mineral structure and physical features of the country, which will be laid before the Geological Society of London, as soon as, with the assistance of my fellow-labourers, I shall have prepared the materials for the public eye. In the mean time the friends of science must be happy to learn, that

Phil. Mag. S. 3. Vol.19. No. 126. Dec. 1841. $2 \mathrm{E}$ 
the Emperor, his ministers and officers have powerfully and kindly contributed to these results by every possible aid and support which geologists could receive. Desirous that this inquiry should be rendered as perfect as circumstances will admit, His Imperial Majesty has graciously authorized the Minister of Finance, the Count de Cancrine, to permit Count Keyserling to visit this country during the winter, to cooperate with myself, whilst General Tcheffkine, the chief of the Staff of the Mining Corps, and so well known to many of my English friends, has obtained permission for Lieut. Koksharoff to be among us for a season, to complete his studies, and acquire a correct knowledge of those British strata with which the deposits of our ancient allies and kind friends have been compared.

16 Belgrave Square,

I remain, dear Sir, yours most faithfully, Nov. 5, 1841. Roderick Impey Murchison.

Letter to M. Fischer de Waldheim, Ex-President of the Society of Naturalists of Moscow.

My dear Str, (Translation.)

As you have taken a lively interest in the success of the geological expedition which $I$ have just completed, accompanied by my friends M. de Verneuil, Count de Keyserling, and Lieutenant Koksharoff, I hasten to communicate to you some of its chief results; and I do so with real pleasure, because in requesting you to present them to the Society of Naturalists of Moscow, I acquit myself of a duty towards a distinguished body which has done me the honour of placing my name in the list of its foreign members.

The wide extension in the North of Russia of the Silurian, Devonian and Carboniferous Systems, as proceeding from the last year's survey, by the same observers and our firiend the Baron A. de Meyendorf, is already known to you from the abstracts of memoirs communicated to the Geological Societies of London and Paris. Our principal objects this year were, 1st. To study the order of superposition, the relations and geographical distribution of the other and superior sedimentary rocks in the central and southern parts of the empire. 2nd. To examine the Ural Mountains, and to observe the manner in which that chain rises from beneath the horizontal formations of Russia. 3rdt. To explore the carboniferous region of the Donetz, and the adjacent rocks on the Sea of Azof.

Our last year's survey had pretty nearly determined the limits of the great tract of carboniferous limestone of the North of Russia. On this occasion we have added to its upper part 
that remarkable mass of rock which forms the peninsula of the Volga near Samara, and which, clearly exposed in lofty, vertical cliffs, and charged with myriads of the curious fossils Fusilina, constitutes one of the striking features of Russian geology.

The carboniferous system is surmounted, to the east of the Volga, by a vast series of beds of marls, schists, limestones, sandstones and conglomerates, to which I propose to give the name of "Permian System," because, although this series represents as a whole, the lower new red sandstone (Rohte todte liegende) and the magnesian limestone or Zechstein, yet it cannot be classed exactly (whether by the succession of the strata or their contents) with either of the German or British subdivisions of this age. Moreover the British lithological term of lower new red sandstone*, is as inapplicable to the great masses of marls, white and yellow limestones, and gray copper grits, as the name of old red sandstone was found to be in reference to the schistose black rocks of Devonshire.

To this "Permian System" we refer the chief deposits of gypsum of Arzamas, of Kazan, and of the rivers Piana, Kama and Oufa, and of the environs of Orenbourg; we also place in it the saline sources of Solikamsk and Sergiefsk, and the rock salt of Iletsk and other localities in the government of Orenbourg, as well as all the copper mines and the large accumulations of plants and petrifled wood, of which you have given a list in the 'Bulletin' of your Society (anno 1840). Of the fossils of this system, some undescribed species of Producti might seen to connect the Permian with the carboniferous æra; and other shells, together with fishes and Saurians, link it on more closely to the period of the Zechstein, whilst its peculiar plants appear to constitute a Flora of a type intermediate between the epochs of the new red sandstone or "trias" and the coal-measures. Hence it is that $I$ have ventured to consider this series as worthy of being regarded as a "System."

The overlying red deposits which occupy a great basin in the governments of Vologda and Nijui Novogorod, have not as yet been found to contain any organic remains except minute Cyprides and badly preserved Modiola; but when we take into consideration their thickness, geological position, and mineral characters, we are disposed to think that they may at some future day be identified with a portion of the "Trias" of German geologists. I am strengthened in this opinion by Count Keyserling's discovering, during our tour at Monte Bogdo, certain fossils which are unknown in other parts of Russia, but which are associated with the Ammonites Bogdoanus already described by Von Buch, and which that distinguished geologist refers to the type of the muschelkalk.

- See Silurian Bystem p. 54. $2 \mathbf{E} 2$ 


\section{$420 \mathrm{Mr}$. Murchison's Sketch of some of the principal Results}

True lias does not exist in Russia, as Von Buch had decided from an examination of fossils sent to him, but the Jurassic or oolitic series is divisible into two stages. The lowest of these, which is much more developed than the upper, never occupies any considerable tract of country, being either distributed in patches, or hidden by newer accumulations. From the eastern flanks of the Ural chain in the $64^{\circ}$ of N. latitude to the Caspian Sea, it preserves nearly the same mineral and fossil characters. This formation represents the inferior and middle oolite. The ferruginous sands, calcareous grits, and black schists of the Moskwa are of this age; and also those beds which we examined last year on the Voiga between Kostroma and Kinshma, at Makarief upon the Unja, as well as those shales and sands which we have seen this year in many other localities, particularly between Arzamas and Simbirsk, between Syzran and Saràtoft, at Saragula, and on the river Ilek near Orenbourg.

The upper oolitic group occurs in several situations along the Donetz, where it was first recognized by Major Blöde. It is calcareous, often oolitic, of light yellow colour, and contains many Trigonice, Nerinea, \&c., which enable us to compare it with the upper Jura of the Germans, or Portland and Coral rag division of my own country.

The cretaceous system, though composed of very different beds of marls, white chalk, sands and grits (sometimes green), offers for the most part the fossils of the white chalk of Earope, such as the Inocerami (Catillus), Belennites mucronatus, Ostraa vesicularis, Terebratula carnea*.

Above the cretaceous system, we have not been able to discover in any part of Russia, except in the Crimæa, the "nummulite limestone" which there sets on, and acquires a great importance in its range through Georgia, Egypt, and the Mediterranean basin.

The equivalents of the lower tertiary formations (Eocene of Lyell) seem to exist in one part only of your country (S. of Saratoft). On the other hand, the middle and upper tertiaries (Miocene and Pleiocene) cover large surfaces on the Lower Volga, in Podolia, Volhynia, and also along the shores of the Sea of Azof and the Black Sea, where the youngest of these strata, very much resembling the "upper crag" of Norfolk, are beautifully displayed.

I have not time to enter upon the numerous and inter-

* After this letter was written, we found in the collection of Professor Eichwald at St. Petersburgh, a fine specimen of Exogyra and other fossils in a green sandstone from the Lower Volga, sent to him from a locality/well known to us, which leaves little doubt of the existence also of a true representative of our greensand.-R. I. M. 
esting phænomena of the Ural Mountains, the examination of which occupied us nearly three months. We there studied alternately the wonders of the gold alluvia, the sites of the entombment of your great mammalia, and sought for the causes of the astonishing metamorphism of the sedimentary rocks of that chain. For an explanation of the last class of phænomena, the works of Humboldt and Gustaf Rose must always be consulted. I will on this occasion simply say, that far from being:primitive, as was supposed, this chain, with the exception of its eruptive masses, is entirely composed of Silurian, Devonian and Carboniferous rocks, more or less altered and crystallized, but in which nevertheless we have been able to recognize in a great number of localities my own Pentamerus $K n i g h t i i^{*}$, and many fossils which clearly define the age of the other strata. 'These rocks, though much broken up, are arranged in parallel bands, the mean direction of which in the North Ural is from $N$. and by W. to $S$. and by $E$., whilst in the South Ural, trending N. and S., they assume a fan-shaped arrangement, spreading out towards the southern steppe of the Kirghis, where, interlaced with porphyries and other trap-rocks, they are often converted into the far-famed jaspers of this region.

Still less can I now pretend to treat of the great carboniferous region of the Donetz; for without entering into details concerning this southern tract, so valuable to the future interests of Russia, I cannot render it the justice which it merits. Still I may say to you as a geologist, that its numerous beds of coal (bituminous and anthracitic), with its grits and shales, are completely subordinate to the mountain limestone series, and represent in no sense the coal-fields of Great Britain, Belgium, and France.

In concluding, however, I must tell you of a very interesting discovery we made in returning from Taganrog to Petersburgh. Count Keyserling took the line of Voroneje and the Don, and M. de Verneuil and myself that of Koursk, Orel and the river Oka, and on meeting at Moscow our results completely agreed. $\dagger$ It was, as you know, generally believed up to this moment, that central Russia presented a regular succession from older to younger deposits as you proceeded from north to south. This is not the case. $A$ great axis of Devonian rocks or old red sandstone, having a width of at least 120 miles, rises in the heart of the country around Voroneje and Orel, and stretches to the W.N.W., in which

- Silurian System, p. 615.

t Colonel Helmersen, so distinguished for his geographical and geological researches in Russia, also examined the tract near Orel in the course of the summer, and had come to the same conclusions as our party. I was however unacquainted with his opinion when I wrote this letter.-R. I.M. 
direction it probably connects itself with deposits of the same age in Lithuania and in Courland. This discovery seems, indeed, to have an intimate relation to one which we made in entering Russia early in the spring, near to Schavli in Lithuania, of much red ground and a band of upper Silurian rocks. In fact it also explains the cause of the great difference which exists between the deposits of the carboniferous basin of the Donetz and those of your Moscow region, now proved to constitute a vast basin. For as the two seas, in which these deposits were accumulated from high antiquity, were separated by the ancient lands in question, so must we infer that the conditions and nature of their shores, their rivers, their currents and bottoms (on which of course the nature of marine deposits depend), must have been essentially different.

This discovery also proves the symmetry of the opposite edges of the Moscow basin; since in advancing from the governments of Tula and Kaluga on the south, we see the same ascending order as that which we before described in the Waldai Hills on the north. In both tracts the Devonian or old red rocks, with Holoptychius Nobilissimus, and many fishes and shells of that system well known in the British Isles*, pass under the lowest strata of the carboniferous æra, and serve as a base line to those thin beds of poor coal associated with Unio sulcatus and Productus gigas (hemisphericus, Sow.), which are at present the subject of new researches on the part of the Russian Government.

The enormous space we traversed and examined, in all between 13 and 14 thousand miles, might well astonish you, if I did not assure you, that the arrangements for this journey, undertaken under the auspices of the Minister of Finance, Count de Cancrine, were admirably prepared by General Tcheffkine, whose clear directions, united to that spirit of hospitality which characterizes all Russians, and above all the inhabitants of the Ural and Siberia, rendered every enterprise feasible, and enabled us to overcome every obstacle.

I shall communicate to you at a later date, and before our large memoir is prepared, the general table of the order of superposition of all the formations of Russia, with sections + .

Accept, dear Sir, the assurance of the affection and esteem of your devoted servant,

Roderick Impey Murchison, President of the Geol. Society of London.

To His Excellency M. Fischer de Waldheim.

- See Silurian System, p. 599.

+ Theae documents, which were laid before His Imperial Majesty in MSS., are now in the hands of the engraver. 